\title{
'Only a Pawn in their Game?' Civil Rights Sounding Signatures in the Summer of 1963
}

\author{
FRANK MEHRING
}

Contemporary reports had been surprisingly quiet about the sounds and soundtrack of the March on Washington for Jobs and Freedom on 28 August 1963. When Lerone Bennett Jr. from EBONY reported on the March on Washington (in the November issue of 1963), music was more or less absent. Mehring is interested in the musical dimension of the March on Washington in order to explore the nexus of music, politics and protest. The shared experience of listening to music and singing is often pushed to the margins in socio-political and historical accounts of central moments of change. In order to understand the function of music during the March on Washington, Mehring goes beyond sociological, linguistic and textual analysis. Music underpins social movements and can strengthen an imaginary community of protesters. Musicians become truth bearers to the political causes and the agenda of the March on Washington. The analysis of what Mehring calls "sound signatures" at the March on Washington reveals that the mediation of the event often determines what and how music is remembered, or even erased from memory. For Bob Dylan, the song "Only a Pawn in their Game" (recorded on 7. Aug. 1963) showed both the power of folk music to critically comment on political issues, but also its limitations as a "musical weapon." Mehring's analysis reveals that, to a certain degree, Dylan found himself to be "a pawn in the game" of the civil rights movement.

As Pete and I traveled to Washington for President Obama's Inaugural Celebration, he told me the entire story of "We Shall Overcome." How it moved from a labor movement song, and with Pete's inspiration, had been adapted by the civil rights movement. That day [January 18, 2009] as we sang "This Land Is Your Land," I looked at Pete, the first black president of the United States was seated to his right, and I thought of the incredible journey that Pete had taken. My own growing up in the Sixties in towns scarred by race rioting made that moment nearly unbelievable, and Pete had 30 extra years of struggle and real activism on his belt. He was so happy that day. It was like, "Pete, you outlasted the bastards, man"!

Bruce Springsteen on the We Are One event, May 3, 2009

The We Are One event to celebrate the inauguration of the first black president was in many ways tied to the speech by Martin Luther King Jr. gave at the same location in front of the Lincoln Memorial in Washington, DC more than half a century before. The inauguration was flanked by an impressive line-up of musicians: Bon Jovi, Garth 
Brooks, Beyonce, Shakira, James Taylor, and many more, who paid tribute to the election of Barack Obama by covering a large musical spectrum from rock, country, singer-songwriter to soul, funk, and contemporary R\&B. The motto of the concert "We are one" and the performance of "This Land is Your Land" by Pete Seeger created a direct link to the musical spirit which permeated the summer of 1963 and culminated in the March on Washington for Jobs and Freedom on August 28, 1963. In his speech at the Lincoln Memorial on January 18, 2009, Obama connected Abraham Lincoln with Martin Luther King, Jr. in the following fashion: "Directly in front of us is a pool that still reflects the dream of a King, and the glory of a people who marched and bled so that their children might be judged by their character's content. And behind me, watching over the union he saved, sits the man who in so many ways made this day possible."

Obama evoked a national imaginary that united the people of the United States, namely the shared sense of freedom expressed in the founding documents of the United States, referenced in Lincoln's Gettysburg Address and Martin Luther King's speech at the March on Washington. While most Americans and people around the world have heard at least soundbites of the famous "I have a dream" speech, be it in school or via samples in popular music, less is known about the actual soundscape and musical agenda during which it was delivered.

Contemporary reports have been surprisingly rare about the sounds and soundtrack of the March on Washington. When Lerone Bennett Jr. from EBONY reported on the March on Washington (in the November issue of 1963), music was more or less absent. As the most significant effect of the march, LIFE magazine emphasized the "Negroes's orderly demonstration of their potential as a moral force" (20). The New York Times zoomed in on the political speeches particularly emphasizing Martin Luther King's speech, which "touched all the themes of the day, only better than anybody else" (1). There is no mention of the power of music, which permeated the event. This silence of the contemporary press begs the following question: What happens to the narrative of the March and its most memorable speech by Martin Luther King Jr. if we put music at the center of our analysis? Is there a musical signature that can be connected to the March on Washington? In how far can we identify, describe, and analyze links between music and the sounds at the March on Washington?

Civil rights historians have traced the radical roots of civil rights to the 1930s and 1940s and have paid particular attention to the speeches on the actual day. Notable works include Charles Euchner's Nobody Turn Me Around (2010), Mary Dudziak's Cold War Civil Rights (2000), Peter Ling's and Sharon Monteith's Gender in the Civil Rights Movement (2004), and Gary Younge's The Speech (2013). Recently, William P. Jones turned to Philip Randolph's observation that the "civil rights Revolution has been caught up in a crisis of victory" $(\mathrm{xx})$ in order to trace the activities of black trade unionists, women as well as men, in their struggle to overcome employment discrimination across the postwar decades. With references to the transnational turn, 
Britta Waldschmidt-Nelson, Marcia Chatelain, and Sharon Monteith produced an edited volume on the transatlantic legacies of the March that have been given special attention in the Bulletin of the German Historical Institute (2015).

Critical approaches to the sounding signatures of the March on Washington have been sparse. Recently, Brian Ward has offered a revealing overview of the "sounds and silences" of the event ("Sounds and Silences" 25). Earlier publications focused on individual artists such as Raymond Arsenault's work on Marian Anderson (2010), Allan M. Winkler on Pete Seeger (2010), individual songs (e.g. Stuart Stotts's work on the song "We Shall Overcome") or genres including folk and jazz (e.g. Scott Saul's Jazz and the Making of the Sixties).

In my approach, I am interested in the musical dimension of the March on Washington in order to explore the nexus of music, politics, and protest. The shared experience of listening to music and singing is often pushed to the margins in sociopolitical and historical accounts of central moments of change. My analysis builds on the works by Ingrid Monson, Burton Peretti, Scott DeVeaux (1997), William Kenney, Samuel Floyed, Ronald Radano, and David Stowe, among others, who have contributed to social and cultural histories of jazz in political contexts, arguing that the practice and emergence of American jazz are closely tied to the discourse on racial segregation. I will engage in debates which understand music, in particular the performance of folk, as an aesthetic practice and glue for a social community. Playing and listening to music can signify political action as scholars of the civil rights movement and the post-war popular left in the U.S. have documented (Denning, Denisoff, Grossberg, Peddie, Saul, Ward, "Sounds and Silences"). While scholars often read political goals of the civil rights and black nationalist movements by pointing towards the musical achievements of jazz musicians such as Louis Armstrong, John Coltrane, Dizzy Gillespie, Miles Davis, and Thelonious Monk (cf. Monson 12), it might come as a surprise that the musicians who actively contributed and performed during the March on Washington did not belong to this group.

In order to understand the function of music during the March on Washington, I will go beyond sociological, linguistic, and textual analysis of previous scholars. For example, Stewart argues that "protest music emerges from a felt need, social anxiety, or a perceived state of relative deprivation" and that "protest songs frequently focus on the identification of a problem situation that requires the movement as a solution, thus legitimizing the movement" (quoted in Knupp 383). What is lacking from this approach is the cultural contextualization of the performance of the songs, as well as the acoustic dimension, the processes of mediation and remediation in synchronic and diachronic fashion. Therefore, I will add an intermedial approach to the analysis of the function of music during the March on Washington. Protest songs are often performed within a network of medial connections and interactions of media. While intermedial studies have been particularly interested in the "relationships between words and images" (Rippl 3), the following article adds the element of music to the analysis. As much as there is no pure medium, as Mitchell argues (94), so is the experience of 
protest songs not limited to only one sense. Rather, protest music of the 1960s was perceived in a synaesthetic environment, be it in concerts, political rallies, or mediated frameworks.

I argue that the March on Washington needs to be conceived as a media event. As such, the media coverage was unprecedented in Washington. Apart from the inaugural of President Kennedy, no other event received the kind of coverage in the media of television, radio, and print as the March on Washington. The experience and memories of participants are inherently different from those who encountered the events via radio or television. As Allison Graham points out, songs and speeches were part of a sound field that included "revving motors, walkie-talkies, twittering birds, crying babies, airplane engines, radios and even occasional silence" (137). Television viewers, however, were exposed to a seamless stream of talk of speakers from the main stage combined with network anchors, field reporters, politicians, and other prominent media representatives. Those who listened to the soundtrack of the march on transistor and car radios, needed to rely on the images published in newspapers published on the day to connect sights and sounds in their imagination. In addition to live coverage on $\mathrm{ABC}, \mathrm{NBC}$, and CBS networks, the U.S. Information Agency exploited the spectacle by producing a 30-minute show called "Hollywood Roundtable." Six celebrities from the field of literature and film were invited to discuss U.S. race relations with the March on Washington as a backdrop. James Baldwin, Harry Belafonte, Marlon Brando, Charlton Heston, director and screenwriter Joseph Mankiewicz, and Sidney Portier became an integral part in the State Government agenda to provide images of peaceful protest, a working democratic exchange of political ideas, and a persuasive look into the current progress on racial equality, which could be distributed to international broadcast stations, schools, and consulates.

This media situation requires that I engage in a practice of reading music as an acoustic phenomenon that links sounds with symbolic, social, political, cultural, and personal meaning. My comparative analysis builds on recent developments in the field of sound studies as a reaction to changes in culture and technology as well as interdisciplinary work related to visual studies. I do not want to limit my work to the study of sound culture, sonic culture, auditory culture, or aural culture, but rather link the analysis of music to its potential affects, function in cultural memory, distribution channels, and thereby the visual and textual dimension. I agree with Ian Peddie that in order to understand the relationship between popular music and social protest, the approach must reckon with the fact that musical protest is "as fluid as the audiences to which it appeals" (Peddie xvi). Music emerges as a social practice that functions as a kind of "soundtrack" in reference to the civil rights movement and the March on Washington.

Before I take a closer look at a selection of songs performed during the March on Washington, it is crucial to clarify the premises of my project and define the terms. The expression "soundtrack" is borrowed from the world of cinema. Since 19th- 
century lantern shows and the origins of film in the 1890s, music has been played in order to both enhance the emotional impact and to overcome the gap between the technical projection of a fictitious world and the illusion of the real. If we want to understand the function of music in the socio-cultural and political context of oppression and liberation, Siegfried Kracauer's description of film music is particularly helpful. He argues that music provided a "meaningful continuity in time" thus helping the audience to perceive "structural patterns where there were none before" (quoted in Cooke 12). This observation is crucial if we look at the effects music has on the perception of protest and liberation pointing towards the cultural imaginary that is framed, channeled, and controlled by sounds before entering into the collective memory. Considering the function of music as a kind of glue between potentially confusing confrontations, between different visual shots, angles, narratives, and jump cuts in the editing, a soundtrack fulfills a compensatory function. In his work on The Aesthetics and Psychology of the Cinema, the influential French film theorist Jean Mitry explains the connection between visual disruption and the function of our mind to create new continuities. Music plays an important in this process:

It is all too apparent that the editing of a series of fixed shots establishes a feeling of continuity but is unable, unlike moving shots, to create the sensation of the continuous, since this sensation is reconstructed intellectually and not perceived as such - which means that reality appears as though it were an idea or memory; or, to put it another way, it appears restructured. (162)

Memory is restructured through music. Music allows us to create a reasonable narrative out of disjointed sensations. As far as music at the March of Washington is concerned, I would like to distinguish four different types:

1. Classical music and patriotic songs

2. Gospels and spirituals

3. 1960s jazz compositions

4. Folk music and protest songs

1) The main organizers of the March on Washington, with Bayard Rustin in a leading position, decided who was to be included in the musical performances and who was left out. Classical music was supposed to play an important role by inviting well-known soprano singer Marian Anderson to open the formal proceedings on the main stage in the afternoon with the national anthem. The invitation of Anderson to sing in front of the Lincoln Memorial hared back to the famous performance she gave on Easter Sunday in 1939 at the same location. The performance of "America" with the seminal words "from every mountain side let freedom ring" is part of the American history of the struggle for freedom and overcome racial hatred. Since the Daughters of the American Revolution refused to let Anderson sing in Constitution Hall, Eleanor Roosevelt publically criticized the group and resigned her membership. In turn, she helped Anderson perform at the Lincoln Memorial and rallied support of government officials. Together with Roland Hayes and Paul Robeson, Anderson was one of the first black Americans who was internationally recognized as a stellar interpreter of a 
classical repertoire (Southern 410-414). However, Anderson arrived too late on the Mall to perform so ultimately the opera singer Camilla Williams opened the program with her patriotic rendition of "The Star-Spangled Banner" (Jones 193, 198). This decision set the tone for the event using classical music as a reference for cultural selfrecognition.

2) There were a number of gospels such as "Freedom" based on the traditional gospel "Amen" or "Keep your Eyes on the Prize" in which the lyrics of the hymn "Gospel Plough" were modified to fit the civil rights cause. One of the most memorable performances was tied to the so-called "queen of gospel," Mahalia Jackson who offered the musical prelude to Martin Luther King, Jr. "I Have a Dream" speech. Her interpretation of the spiritual "I've Been Buked and I've Been Scorned" was received with rousing applause. The song struck a chord among the audience with its themes of the suffering of African Americans going back to the middle passage, the struggle from bondage to freedom and hope for a better future. Her performance produced, according to Charles Euchner, a sense of unity, an "effect of a whole congregation singing in once voice" (185). As part of the official program, the Eva Jessye Choir from New York performed a number of concertized spirituals, which were arranged as a medley.

One might argue that Martin Luther King, Jr.'s speech can also be considered part of a musical sound signature of the March on Washington. There are two key expressions that King improvised on: "I have a dream" and "Let freedom ring." They can be compared to riffs, as Michiko Kakutani notes. The Oxford English Dictionary defines the noun "riff" as "a short repeated musical phrase, often with a strong or syncopated rhythm, played over changing chords or harmonies or used as a background to a solo improvisation." The repetitive notion of the riff combined with colorful metaphors are reminiscent of blues lyrics. It was the blues singer Mahalia Jackson who can be heard on the recording of King's speech to encourage him to lay aside his carefully orchestrated manuscript and improvise like a preacher or a blues performer. In the kind of call-and-response tradition practiced in the black church's oral tradition, the audience encouraged the speaker with shouts of "Amen," "Preach, Dr. King, preach," and "Dream some more" comments. King sounds out "let freedom ring" eleven times. Like a chorus, the iconic phrase "I have a dream" can be heard nine times. King uses these riffs and weaves them together with anecdotes and a rich reservoir of quotations from historical speeches such as the Gettysburg Address, documents such as the Declaration of Independence, the folksongs of Woody Guthrie, the literary work of Shakespeare, as well as the New and Old Testament. His final lines in the March on Washington speech draw on a spiritual song to encourage the audience's belief in liberation: "Free at last, free at last; thank God Almighty, we are free at last." The speech is a masterpiece in improvisation, allusions, references, and repetitive riffs. As such, the speech represents an essential part of sounding signatures of the March on Washington. 
3) Notably absent from the event were some of the most internationally acclaimed jazz musicians who provided the soundtrack of liberation after WWII, some of whom had become part of the jazz ambassadors program. Musicians of be-bop, hard-bop, and spiritual jazz are often referred to as offering the soundtrack in regards to the civil rights movement. However, none of these musicians actually participated in the March on Washington. What escapes many observers and writers on the March on Washington is the fact that many of the major African-American jazz musicians such as Thelonious Monk, Coleman Hawkins, Art Blakey, Billy Eckstine, Ahmad Jamal, Quincy Jones, Charlie Shavers as well as Abbey Lincoln, March Roach, Duke Ellington, Billy Taylor, Nat Cole, Sammy Davis, and Frank Sinatra performed at two major benefit concerts at the Apollo Theater on August 23 and the New York polo ground on August 25 respectively. Considering the international presence of Louis Armstrong as one of the most visible jazz ambassadors of the 1950s, a number of journalists wondered why he did not perform on the march. While for example Duke Ellington, whom some consider America's greatest composer (Green 1), was supportive of the civil rights movement, his absence is nevertheless striking. As Brian Ward points out, Ellington had been invited but declined to participate ("Sounds and Silences" 36). This decision can partly be explained due to his involvement in a jazz ambassador tour of the Middle East and India, which opened in Damascus, Syria, on September 9, 1963, twelve days after the March on Washington. Ellington preferred to let his music speak for him as the subtitle of his jazz symphony Black, Brown, and Beige suggests: A Tone Parallel to the History of the Negro in America (cf. Morgenstern 157). In the summer of 1963, Ellington worked on a kind of "Gesamtkunstwerk" on the African American experience called My People (Schiff 250). Ellington composed what might be called musical theater for the Century of Negro Progress Exposition in Chicago, which ran from August 16 to September 2, 1963. While the exhibition celebrated the Emancipation Proclamation, the March on Washington provided the political counterpart to the artistic approach in Chicago. On a more economical level, Ellington's dismissal might be related to the specific audience and potential drop in record sales, as Ward suspects: "Indeed there was widespread fear that forthright civil rights advocacy might alienate white fans who had come to think of Ellington as a national treasure but rarely as a political figure" ("Sounds and Silences" 37). The cross-racial appeal of Ellington's music would have fit perfectly well into the integrationist agenda.

4) Folk music played a crucial role in the civil rights movement and was featured prominently on the stages during the March on Washington. In public memory, white folk singers are most prominently remembered. Considering the international fame of Joan Baez, Bob Dylan, Pete Seeger or Peter, Paul and Mary, their contributions to the March on Washington have entered collective memory more forcefully than others, due to media representations in texts, photographs, and documentary films.

Most notably, Bob Dylan performed two songs, which have contributed to the perception that folk music was intrinsically linked to the sounding signature of the 
March on Washington: "When the Ship Comes In" (harmonized by Joan Baez) and "Only a Pawn in Their Game." With Peter, Paul and Mary's famous performance of "Blowing in the Wind," Dylan's art of protest music was also present at the march even if he was not on stage. The folk song "We shall overcome" has been described as the "anthem of America's civil rights movement" (Bobetsky 1), the "Marseillaise" of civil rights (Shelton 130) as well as a "freedom song" (Woodard 99). It is a striking example in which music crosses boundaries on cultural, ethnic, racial, and national levels (Raussert 1). In addition to Joan Baez and several other singers, the Eva Jessye Choir also contributed a version of "We Shall Overcome" crossing the boundaries between concertized spirituals and folk music. As Dylan explained in his autobiographical Chronicles, "We Shall Overcome" was the "spiritual marching anthem of the civil rights movement. It had been the rallying cry for the oppressed for many years" (90). Dylan played an active role as a musician who joined the AfricanAmerican protesters to make his voice heard for the sake of the oppressed. However, his involvement in the civil rights movement is more complex than suggested by the popular references to Dylan as a protest singer.

The music of the March on Washington cannot be seen exclusively from the perspective of the African-American struggle for freedom, but also needs to be understood by drawing attention to the connection between youth, ethnicity, and the folk revival in the early 1960s. While white teenagers in the mid-1950s turned to musical styles such as a rock'n'roll to distance themselves from their parents' generation, the tensions over civil rights and second class citizenship of African Americans, especially in the South, increased the tensions between emerging baby boomers and their parents. During the Kennedy presidency, a large number of white college students began to turn to folk music in order to re-signify the political heritage of the 1930s folk music towards an expression of political dissent. The folk revival of the 1950s and 1960s emerged from the songs of Leadbelly, and John and Alan Lomax ethnomusicological work of archiving folk music. Figures such as Pete and Mike Seeger as well as Phil Ochs, Joan Baez, and Bob Dylan offered some of the most influential contributions to the folk movement. Folk music repertories often have a specific function in order to "motivate the formation and dissolution of groups," as Philip Bohlman points out (288). During the civil rights movement, folk music functioned as a sounding text to give expression to resistance regarding discrimination on racial grounds.

Taylor Branch describes "We Shall Overcome" as a song whose "simple strains and dogged sincerity made the hymn suitable for crisis, mourning, and celebration alike" (310). Turning to Charles J. Stewart's analysis of late 19th and 20th-century protest music with his five categorization of songs into clustered themes, "We Shall Overcome" falls into the third group: "United and Together versus Separate and Divided." Songs in this category appeal to a sense of "unity, organization and commitment" ("The Ego Function" 244). Singing provides a kind of glue between the actors in order to express joint commitment of resistance and the will for change. In 
order to transform the ritual of singing into a visual sign of unity by joining hands, the song needs to be simple enough to learn and perform easily, open enough to express criticism without being limited to a specific issue or policy. At the same time, the song must be able to express a sense of immediacy and forcefulness. In order to avoid confusion through complex historical or political contexts, the expressive dimension of the song must rely on social relationships rather than specific contents or an ideology. "We Shall Overcome" lives up to these requirements. With its simple melody, repetitive musical and lyrical structure, and small tonal range, it is ideally suited for anybody to sing along almost instantly. At the end of each verse, there is a quarter rest, which allows the lead singer to announce the first line of the next verse, which then is repeated three times. In addition, the melodic progression is mostly based on easy to sing chromatic intervals. In terms of its lyrics and the experience of bonding through singing (and in many cases of the ritual of holding hands while singing), the song helps to create a sense of self-esteem among the performers.

Bob Dylan was one of the iconic figures who emerged from this musical spirit and became a leading voice for his generation. With his nasal, thin, and sometimes broken voice accompanying his sharp poetical compositions on acoustic guitar, he clearly evoked the Woody Guthrie's folk songs and political messages of the preceding generation. For white folk music performers, the 1963 Newport Folk Festival on July 25 and 26 functioned as a kind of warm-up for the March on Washington. Attracting about 40,000 visitors, the line-up at the final concert featured Theodore Bikel, Bob Dylan, Joan Baez, Pete, Paul, and Mary, Pete Seeger as well as Ruth Mae Harris, Charles Neblett, Cordell Reagon, Bernice Johnson, who joined together in singing "We Shall Overcome" (cf.. Cohen 237). The well-known photo by John Byrne Cooke shows performers joining hands as a sign of solidarity with the African-American struggle for civil rights. The singing of "We Shall Overcome" is part of a performance which links political themes with music, singing, and social gestures to signify unity in protest. W.E.B. DuBois has called African Americans to "close ranks" during times of war (242). The reference to the military vocabulary of a "march" on the capital with singers of different skin color joining hands translates DuBois's call for unity into a powerful symbol with music as the glue to "close ranks." Many photos of the March on Washington show the audience in a similar position of joined hands like the photo from the 1963 Newport Folk Festival.

Insert picture 1 here: [1 we_shall_overcome_at_newport]

Ill. 1: Photograph by Peter Byrne Cooke, Newport. Performing "We Shall Overcome," (left to right): The group Peter, Paul, and Mary (Paul Stookey, Mary Travers, Peter Yarrow), Joan Baez, Bob Dylan, Ruth Mae Harris, Charles Neblett, Cordell Reagon, Bernice Johnson, and Pete Seeger. Photographed on July 26, 1963, by John Byrne Cooke at the Newport Folk Festival, singing "We Shall Overcome" with a standing audience of 13,000 joining in.

Insert picture 2 here: [2 Joan_Baez_Bob_Dylan] 
Ill. 2: Photograph of Joan Baez and Bob Dylan performing at the March on Washington, Aug. 28, 1963. Rowland Scherman, U.S. National Archives and Records Administration. (Public domain).

The singing of the "We Shall Overcome" has by now become part of a ritual and visual signal of joining hands and closing ranks. As the program for the main stage of the March on Washington shows, the song functioned as an overarching theme of the event. "WE SHALL OVERCOME" is printed in bold capital letters at the end of the program. Visually, it offers both an agenda and conclusion. Musically it resembles a culmination of the day by turning to music to perform the integrations agenda in the struggle for equality and freedom. As a universal theme, "We Shall Overcome" translates Friedrich Schiller's "Ode to Joy" at the end of Beethoven's Ninth Symphony from the classical concert stage to the political stage. "Alle Menschen werden Brüder" [in the sense of "all men become brothers" or "all people are united"] touches on similar themes on a poetical and musical level. The final movement of Beethoven's symphony suggests that the musicians, the choir, and the audience are invited to get a glimpse of the transcendental joy associated with universal brotherhood. The theme of human bonding, of overcoming what separates people, be it racial, ideological, or religious differences, is recognized all over the world. In the German context of the fall of the Berlin Wall, Leonard Bernstein conducted the Ninth Symphony to be a powerful symbol in 1989. The people at the Brandenburg Gate could re-unite with their fellow German citizens, who had been separated by a seemingly unsurmountable wall defined by the ideological oppositions of the Cold War. Beethoven's anthem sounded out the hope for unity at the Brandenburg Gate. "We Shall Overcome" touches on similar themes, albeit in a specific U.S.-American context defined by racial segregation and the trauma of slavery.

Insert picture 3 here: [3 March-on-washington-jobs-freedom-program]

Ill. 3: March on Washington for Jobs and Freedom program, Aug. 28, 1963 (public domain)

When Dylan entered the stage at the March on Washington, the announcer recognized the tremendous applause and concluded the artist needed no further introduction. Apart from his achievements as a singer and songwriter, by 1963 Dylan had become a media phenomenon and, indeed, did not need an introduction. While many musicians gained fame and popularity by appearing in the prestigious Ed Sullivan Show, Dylan used the show to his advantage by not appearing. In 1963, Dylan walked off the set in fury after rehearsing his "Talkin' John Birch Society Blues" since the producers considered the song too controversial at the time for a television broadcast on CBS. In a satirical fashion, Dylan's paranoid narrator falls victim to the extreme rightwing, antiCommunist organization propaganda that Communists are allegedly invading the United States. The confrontation between Dylan and CBS made front-page news. Nationwide, Dylan became recognized as a protest singer who would not sell out to 
the mainstream media. There is an ironic twist that Dylan's refusal to appear in the medium television turned him into a media phenomenon. "The uproar about this blatant act of censorship did Dylan considerably more good, by portraying him as a rebel and counterculture hero, than if he had appeared on the show and performed ... to an uncaring national TV audience" (Heylin 71). Within the folk movement, he was appreciated for his uncompromising integrity (cf. Inglis 572).

Another crucial performance which connected the early protest songs of Dylan with the cause of the March on Washington was his appearance at a voter registration rally in Greenwood, Mississippi, organized by the Student Nonviolent Coordinating Committee (SNCC) on July 6, 1963. In Greenwood, Dylan performed one of the songs, which he also deemed most appropriate for his appearance in front of the Lincoln Memorial to join the cause of the marchers: "Only a Pawn in Their Game." Interestingly, it was Pete Seeger, who requested the song from Dylan. The song is an appropriate selection due to the timely tragedy of the killing of African American civil rights activist Medgar Evers. The performance creates an intertextual link with the program with speeches on the main stage. Following the opening remarks by A. Philip Randolph and remarks by Dr. Eugene Carson Blake (Vice chairman, Commission on Race Relations of the National Council of churches of Christ in America), the "tribute to Negro Women Fighters for Freedom" was presented by none other than Mrs. Medgar Evers, wife of the slain NAACP leader, to honor Daisy Bates, Gloria Richardson, and Rosa Parks among others.

In the lyrics, Dylan talks about the assassination of the civil rights activist Medgar Evers, who was shot on June 12, 1963 in Jackson, Mississippi. Rather than exclusively blaming the white Southerner, he identifies the real criminals behind the deed in the political and social milieu responsible for propagating racial hatred and violence. Apart from the Ku Klux Clan, Dylan refers to the political rulers: "The deputy sheriffs, the soldiers, the governors get paid/And the marshals and cops get the same/But the poor white man's used in the hands of them all like a tool" (Margotin and Guesdon 96). The assassin is only a small wheel in a large machine that still runs on the fuel of slavery, racial segregation, and class boundaries. In a surprising twist, Dylan takes away part of the blame from the perpetrator in order to address larger political and philosophical issues that remained unresolved in the United States:

From the poverty shacks, he looks from the cracks to the tracks/And the hoofbeats pound in his brain/And he's taught how to walk in a pack/Shoot in the back/With his fist in a clinch/To hang and to lynch/To hide 'neath the hood/To kill with no pain/Like a dog on a chain/He ain't got no name/But it ain't him to blame/He's only a pawn in their game. (https://bobdylan.com/songs/only-pawn-their-game)

The critical approach to Southern racialism, the suppression of both African Americans and "poor white men," and what Shelton called the "confusion of victim with victimizers" (153), complicated the binary opposition of "whites," "blacks," and racial hatred. 
After the March on Washington, Dylan became suspicious of his involvement in protest movements and rebelled against his classification as protest singer. On March 15, 1965, President Lyndon B. Johnson made a speech to Congress featuring the headline "We Shall Overcome" to comment on the march from Selma to Montgomery to register African Americans to vote. In an interview in his Biograph, Dylan critically commented on the use of the song title, which Jim Forman dismissed as an "empty symbol" (quoted in Marqusee 132). "It's like Lyndon Johnson saying we shall overcome to a nationwide audience, ridiculous ... there's an old saying, 'if you want to defeat your enemy, sing his song' and that's pretty much still true" (132). In Chronicles Dylan commented that Lyndon B. Johnson had "interpreted the idea [behind "We Shall Overcome"] to suit himself, rather than to eradicate it" (90). In other interviews, Dylan explained that protest songs were problematic for various reasons. In addition to his conviction that people did not listen closely enough, Dylan recognized that "songs aren't going to save the world" (Shelton 201). Even more explicit, he felt that he had been used by the protest movement, and to a certain degree losing control over his performances.

The civil rights and protest songs, I wrote when nobody else was writing the. Now, everyone is. But I've found out some things The groups promoting these things, the movement, would try to et me involved with them, be their singing spokesman - and inside these groups, with all their president-vice-president-secretary stuff, it's politics. Inside their own pettinesses they're as bad as the hate groups. (201)

Another moment of disillusionment for Dylan might have been the film footage of his performance at the March on Washington. After the announcement of his performance of "Only a Pawn in their Game," the organizers on the main stage turned their backs on Dylan, standing behind him, talking, and openly expressing no particular interest in what he was going to communicate through his performance. This footage offers another clue for Dylan's growing disenchantment with his status as a protest singer who could be hired and exploited for a variety of agendas and events. Dylan went electric after his realization that he had become "a pawn" in other people's game. Hence, the electrification of his music is also a sounding signifier for a change of his musical politics.

\section{Conclusion}

Music underpins social movements and has the potential to strengthen an imaginary community of protesters. Musicians become truth bearers to the political causes and the agenda of the March on Washington. The analysis of the sound signatures at the event has revealed that the mediation of the event often determines what and how music is remembered, or even erased from memory. We have come to a surprising conclusion: on the seminal day of African-American protest and struggle for emancipation, the sounding signature of the struggle for freedom was not so much tied to jazz but rather classical music, gospels, and particularly folk music. The latter 
played a crucial role as an artistic glue for the integrationist approach furthering solidarity across the "color line" in the DuBoisian sense. The hymn of the folk revival, "We Shall Overcome," functioned as a musical leitmotiv and political slogan linking the social protest of folk musicians of the 1930s with the cause of the civil rights movement. While iconic jazz musicians and composers such as Duke Ellington and Louis Armstrong were travelling the world as jazz ambassadors, the cross-racial appeal of, for example Ellington's music, was notably absent.

For Dylan, the song "Only a Pawn in their Game" signified the power of folk to critically comment on political issues like the violent death of Medgar Evers. It also showed the limitations of folk music and that it might ultimately be overestimated as a "musical weapon." To a certain degree, Dylan found himself to be "a pawn" in the game of the civil rights movement. After the March on Washington, Dylan turned away from his earlier musical expression of protest within the traditional genre of folk performances and moved towards an electrified sound. The sounding signature of the summer of 1963 with Bob Dylan as one of the most prominent media figures was defined by the acoustic guitar and the singer expressing his fears, anger, and hopes between protest and the mantra of a self-fulfilling prophesy, "We shall overcome." After the March on Washington, Dylan recognized that in order to avoid complicity and regain his voice as an individual, he did not need to change his tune but rather his sound.

\section{Coda}

While scholars such as Jeffrey Pasley argue that in the 1960s, "rock and liberal social protest were inseparably associated" (22), the rock rebels, soul, and pop artists at the Obama inauguration became embedded in a political agenda to celebrate the "magical moment" (Mazloomi 36) of the first day in office of the first African-American U.S. president. Considering the links between popular music and social protest, it seemed as if the potential power of popular music to function as a means of protest against the political establishment had been suspended. Former songs of protest were re-codified as songs of victory. In the late 1950s, Pete Seeger emerged as a left-wing political dissenter. He continued to present a referential figure, who could be called upon to testify to the success of the civil rights movement simply through being (still) on stage at the very place where the March on Washington once found its iconic media manifestation with Martin Luther King Jr.'s memorable line "I have a dream." In 1963 , the political rally and musical performances attracted more than 200,000 visitors at the actual location. From a media perspective, the live recordings and presence of reporters reached an even larger international audience. In 2009, the "resisting muse," to use the metaphor which Ian Peddie employed to describe protest music (xviii), has been turned into a supporting muse. The gathering of artists includes many of those who in their career had either used their artistry as a form of protest, be it against racial politics of the 1970s or Reaganomics in the 1980s, the raft of rock protest songs 
recorded in response to George W. Bush's foreign politics in the Middle East, or the domestic policies that infringe on civil liberties.

The performance of Pete Seeger is no longer tied to a sense of protest. Rather, it is perceived through the filter of nostalgia. This Land is Your Land, one of the signature songs of the 1960s civil rights movement, combined with the presence of the 91 year-old performer and the visual link via the iconic instrument of folk music, the banjo, is likely to trigger an aesthetic transfer in the mind of the audience. The performance allows the audience to imagine a community bound by a sense of protest. Pete Seeger's performance suggests a sense of closure, of protest having come full circle. At the same time, the concert at the inauguration in which well-known artists advocate, laude, or endorse the political cause of a president (or his campaign beforehand), is in line with a style of politics which has become personalized. Elections, as John Street argues in Music and Politics, are organized "around displays of personal style" (53), often associated with popular music. If our modern era is defined by "post-democracy," as Colin Crouch believes, then the rituals of democracy, allegedly devoid of substance, are related to pop concerts in which a politically engaged musician speaks to a community of listeners or fans in a performance of conventions that only appear to have a clearly identifiable political dimension.

Obama explained that it was jazz, which more than any other musical style represents the music whose development was driven by an "unmistakable American spirit." During the jazz gala at the White House on April 30, 2016, he reaffirmed this connection between jazz and the struggle for freedom which defined American progress and hopes for the future. "It is, in so many ways, the story of our nation's progress: Born out of the struggle of African-Americans yearning for freedom. Forged in a crucible of cultures - a product of the diversity that would forever define our nation's greatness" (Chinen C3). References to the folk-inspired soundtrack of the March on Washington were notably absent on that day. It seemed, for a moment, as if the spirit of resistance inscribed in the song "We Shall Overcome" - while still very much at the center on Bruce Springsteen's 2006 album The Seeger Sessions and referenced during the George W. Bush era as a song about "issues that have still not been resolved" - had become something like a nostalgic relict of the past. The sounding signature of the civil rights movement had been replaced by a diversity of sounds of the 21 st century entertainment music. While folk music informed the March on Washington, Obama chose jazz to become the soundtrack of his presidency at the International Jazz Day (April 30, 2016), which took place at the White House. During the event that some consider the "greatest jazz concert the world had seen in a long time" (Kümmel 43), Obama referenced Dizzy Gillespie, who ran for the presidency in 1964, to turn his dream into a reality: the desire to transform the White House into a "Blues House."

\section{Works cited}


Arsenault, Raymond. The Sound of Freedom: Marian Anderson, the Lincoln Memorial and the Concert that Awakened America. New York: Bloomsbury Press, 2010. Print.

Bennett, Lerone, Jr. "Biggest Protest March.” EBONY. 14.1 (Nov. 1963): 29-47. Print.

Bobetsky, Victor V., ed. "Introduction." We Shall Overcome. Essays on a Great American Song. Lanham, Boulder, New York, London: Rowman \& Littlefield, 2015. 1-1. Print.

Bohlman, Philip V. "Immigrant, Folk and Regional Musics in the Twentieth Century." The Cambridge History of American Music. Ed. David Nicholls. Cambridge: Cambridge UP, 2008. 276-308. Print.

Branch, Taylor. Parting the Waters: America in the King Years 1954-63. New York: Simon \& Schuster, 1988. 3-17. Print.

Buch, Esteban. Beethoven's Ninth: A Political History. Chicago: U of Chicago P, 2003. Print.

Chatelain, Marcia, and Britta Waldschmidt-Nelson. "Introduction: Untold Stories: The March on Washington - New Perspectives and Transatlantic Legacies." Staging a Dream: Untold Stories and Transatlantic Legacies of the March on Washington. Ed. Britta Waldschmidt-Nelson, Marcia Chatelain, and Sharon Monteith. Bulletin of the German Historical Institute 11 (2015): 5-24. Print.

Chinen, Nate. "International Jazz Day Enlivens the Capital." The New York Times. (2 May 2016): C3. Print.

Cohen, Norm. Folk Music: A Regional Exploration. Westport, CT: Greenwood Press, 2005. Print.

Cooke, Mervyn. A History of Film Music. Cambridge: Cambridge UP, 2008. Print.

Cowger, Thomas W, and Sherwin J. Markman, eds. Lyndon Johnson Remembered: An Intimate Portrait of a Presidency. London: Rowman \& Littlefield Publishers, 2003. Print.

Crouch, Colin. Post-Democracy. Cambridge: Polity, 2004. Print.

Euchner, Charles. Nobody Turn Me Around: A People's History of the 1963 March on Washington. Boston: Beacon Press, 2010. Print.

Denisoff, R. Serge. Great Day Coming: Folk Music and the American Left. Urbana: U of Illinois P, 1971. Print.

Denning, Michael. The Cultural Front: The Laboring of American Culture. New York: Verso, 1996. Print.

Dudziak, Mary. Cold War Civil Rights: Race and the Image of American Democracy. Princeton: Princeton UP, 2000. Print.

DeVeaux, Scott Knowles. The Birth of Bebop: A Social and Musical History. Los Angeles: U of California P, 1997. Print.

Dylan, Bob. Chronicles. Volume 1. New York: Schuster \& Schuster, 2004. Print.

Euchner, Charles. Nobody Turn Me Around: A People's History of the 1963 March on Washington. Boston: Beacon, 2010. Print.

Flannery-McCoy, Christopher. "Analysis and History of Major Choral Arrangements of "We Shall Overcome." We Shall Overcome. Essays on a Great American Song. Ed. Victor V. Bobetsky. Lanham, Boulder, New York, London: Rowman \& Littlefield, 2015. 59-76. Print. 
Floyed, Samuel. The Power of Black Music: Interpreting its History from Africa to the United States. New York: Oxford UP, 1995. Print.

Gallo, Phil. "Review: 'We Are One: The Obama Inaugural Celebration." Variety. 18 Jan. 2009. Web. 30 May 2017. http://variety.com/2009/scene/markets-festivals/we-are-onethe-obama-inaugural-celebration-1200473270/.

Gilmour, Michael J. The Gospel According to Bob Dylan. The Old, Old Story for Modern Times. Louisville: Westminster John Knox Press, 2011. Print.

Graham, Allison. "Hollywood Activism, Daytime Verité, and the March on Washington." Staging a Dream: Untold Stories and Transatlantic Legacies of the March on Washington. Ed. Britta Waldschmidt-Nelson, Marcia Chatelain, and Sharon Monteith. Bulletin of the German Historical Institute 11 (2015): 131-148. Print.

Green, Edward, ed. "Editor's Introduction: Ellington and Aesthetic Realism." The Cambridge Companion to Duke Ellington. Cambridge: Cambridge UP, 2014. 1-18. Print.

Grossberg, Lawrence. "Another Boring Day in Paradise: Rock and Roll and the Empowerment of Everyday Life." Popular Music. Critical Concepts in Media and Cultural Studies. Ed. Simon Frith. Vol. 2. London and New York: Routledge, 2004. 311342. Print.

Heylin, Clinton. Dylan: Behind the Shades. London: Viking, 1991. Print.

Inglis, Ian. "The Ed Sullivan Show and the (Censored) Sounds of the Sixties." The Journal of Popular Culture 39.4 (2006): 558-575. Print.

Jones, William. P. The March on Washington: Jobs, Freedom, and the Forgotten History of Civil Rights. New York: W.W. Norton, 2014. Print.

Hill, Johnny Bernard. The First Black President: Barack Obama, Race, Politics and the American Dream. Palgrave MacMillan: New York City, 2009. Print.

Kakutani, Michiko. “The Lasting Power of Dr. King's Dream Speech.” The New York Times 27 Aug. 2013. Web. 16 May 2017.

http://www.nytimes.com/2013/08/28/us/the-lasting-power-of-dr-kings-dreamspeech.html.

Kenney, William Howland. Chicago Jazz: A Cultural History, 1904-1930. New York: Oxford UP, 1993. Print.

Knupp, Ralph E. "A Time for Every Purpose Under Heaven: Rhetorical Dimensions of Protest Music.” Southern Speech Communication Journal 46.4 (1981): 377-389.

Kümmel, Peter. "Das Fest.” Die ZEIT 20, 4 May 2016. 43. Print.

Ling, Peter, and Sharon Monteith. Gender in the Civil Rights Movement. Rutgers UP, 2004. Print.

Malcolm X. "Message to the Grassroots." Malcolm X Speaks. Selected Speeches and Statements. Ed. George Breitman. New York: Grove Press, 1990. Print.

Margotin, Philippe, and Jean-Michel Guesdon. Bob Dylan: All the Songs. The Story Behind Every Track. New York: Black Dog \& Leventhal, 2015. Print.

Marqusee, Mike. Wicked Messenger: Bob Dylan and the 1960s. Chimes of Freedom. Revised and Expanded. New York: Seven Stories Press, 2005. Print. 
Mazloomi, Carolyn L. Journey of Hope: Quilts Inspired by President Barack Obama. Minneapolis: Voyageur Press, 2010. Print.

Mehring, Frank. The Democratic Gap: Transcultural Confrontations of German Immigrants and the Promise of American Democracy. Heidelberg: Winter, 2014. Print.

—. "Liberation Songs: Music and the Cultural Memory of the Dutch Summer of 1945." Politics and Cultures of Liberation: Media, Memory, and Projections of Democracy. Ed. Hans Bak, Frank Mehring, and Mathilde Roza. Amsterdam: Brill, 2018. 149-176. Print.

- Soundtrack van de Bevrijding. Swingen, Zingen, en Dansen op Weg naar Vrijheid. Nijmegen: Vantilt, 2015. Print.

Mehring, Frank, and Erik Redling, eds. Sound and Vision: Intermediality and American Music. European Journal of American Studies. 12.4. 2017. Web. 23 Oct. 2018. https://journals.openedition.org/ejas/12384

Mitchell, W.J.T. What do Pictures Want? The Lives and Loves of Images. Chicago: U of Chicago P, 2005. Print.

Mitry, Jean. The Aesthetics and Psychology of the Cinema. Bloomington: Indiana UP, 1997. Print.

Monson, Ingrid. Freedom Sounds: Civil Rights Call out to Jazz and Africa. Oxford: Oxford UP, 2007. Print.

Morgenstern, Dan. "The 1960s and 1970s: Triumph and Tragedy." The Cambridge Companion to Duke Ellington. Ed. Edward Green. Cambridge: Cambridge UP, 2014. 154-170. Print.

Pasley, Jeffrey L. "Right Rock: Rock Music and Reaganism." The New Republic 196 (23 Mar. 1987): 22. Print.

Paul, Gerhard, and Ralph Schock, eds. Der Sound des Jahrhunderts: Geräusche, Töne Stimmen 1889 bis heute. Bonn: Bundeszentrale für politische Bildung, 2013. Print.

Peddie, Ian, ed. The Resisting Muse: Popular Music and Social Protest. Burlington: Ashgate, 2006. Print.

Peretti, Burton William. The Creation of Jazz: Music, Race, and Culture in Urban America. Urbana: U of Illinois P, 1992. Print.

Radano, Ronald, and Philip V. Bohlman. Music and the Racial Imagination. Chicago: U of Chicago P, 2000. Print.

Raussert, Wilfried. Cornbread and Cuchifritos: Ethnic Identity Politics, Transnationalization, and Transculturation in American Urban Popular Music. Trier: WVT, 2011. 1-11. Print.

Reston, James. “'I Have a Dream ...': Peroration by Dr. King Sums up a Day the Capital Will Remember." The New York Times (29 Aug. 1963): 1, 6. Print.

Rippl, Gabriele, ed. Handbook of Intermediality: Literature - Image - Sound - Music. Berlin: De Gruyter, 2015. Print.

Saul, S. Freedom is, Freedom Ain't: Jazz and the Making of the Sixties. Cambridge, MA: Harvard UP, 2003. Print. Print.

Schiff, David. The Ellington Story. Berkeley, Los Angeles, London: U of California P, 2012. 
Shelton, Robert. No Direction Home. The Life and Music of Bob Dylan. Revised and updated edition. London: Omnibus Press, 2011. Print.

Southern, Eileen. The Music of Black Americans: A History. 3rd ed. New York: Norton, 1997. Print.

Sterne, Jonathan. The Audible Past: Cultural Origins of Sound Reproduction. Durham: Duke Press, 2003. Print.

Stewart, Charles J. "Championing the Rights of Others and Challenging Evil: The Ego Function in the Rhetoric of Other-Directed Social Movements." Southern Communication Journal 64.2 (1999): 91-105. Print.

- "The Ego Function of Protest Songs: An Application of Gregg's Theory of Protest Rhetoric." Communication Studies 42 (1991): 240-253. Print.

Stotts, Stuart. We Shall Overcome: A Song That Changed the World. Boston: Clarion Books, 2010. Print.

Stowe, David. Swing Changes. Big-Band Jazz in New Deal America. Cambridge: Harvard UP, 1996. Print.

Street, John. Music and Politics. Cambridge: Polity Press, 2012. Print.

"The Washington March: Negroes stage a mighty protest and challenge the country's conscience." N.a. LIFE 55.10 (6 Sept. 1963): 10-29. Print.

Ward, Brian. Just my Soul Responding: Rhythm and Blues, Black Consciousness and Race Relations. London: U of California P, 1998. Print.

- "Sounds and Silences: Music and the March on Washington." Staging a Dream: Untold Stories and Transatlantic Legacies of the March on Washington. Ed. Britta Waldschmidt-Nelson, Marcia Chatelain, and Sharon Monteith. Bulletin of the German Historical Institute 11 (2015): 25-48. Print.

W. E. B. Du Bois. "Close Ranks." July 1918. Let Nobody Turn Us Around: Voices of Resistance, Reform, and Renewal; An African American Anthology. Ed. Manning Marable and Leith Mullings. London: Rowman \& Littlefield Publishers, 2009. (242243). Print.

—. "Germany and Hitler." W. E. B. Du Bois: A Reader. Ed. David Levering Lewis. New York: Henry Holt, 1995. 734-738. Print.

Winkler, Allan M. "To Everything There is a Season": Pete Seeger and the Power of Song. Oxford: Oxford UP, 2010. Print.

Woodward, Patricia, "Beyond 'We Shall Overcome': The Lasting Legacy of Freedom Songs." We Shall Overcome. Essays on a Great American Song. Ed. Victor V. Bobetsky. Lanham, Boulder, New York, London: Rowman \& Littlefield, 2015. 99-120. Print.

Younge, Gary. The Speech: The Story Behind Dr. Martin Luther King Jr. s Dream. Chicago: Haymarket Books, 2013. Print. 